\title{
Herstel van de arbeidsovereenkomst onder de Wwz
}

\author{
De theorie, de statistieken en de parenthesen van de Hoge Raad
}

prof. mr. Ruben Houweling*

\section{Inleiding}

Met de Wet werk en zekerheid (Wwz) heeft de rechtsfiguur van 'herstel' een meer prominente plaats in het ontslagrecht gekregen. Eerder sprak ik reeds mijn verbazing uit dat in veel literatuur wordt gedaan alsof 'veroordeling tot herstel van de arbeidsovereenkomst' een Wwz-noviteit is, terwijl deze figuur al meer dan zestig jaar een plekje in ons arbeidsrecht heeft. ${ }^{1}$ Onder het oude recht kon de werknemer zowel bij onregelmatige opzegging (artikel 7:680 (oud) BW) als bij kennelijk onredelijke opzegging (artikel 7:681/682 (oud) BW) vorderen dat de werkgever werd veroordeeld tot herstel van de arbeidsovereenkomst. Wellicht vanwege de relatieve onbekendheid met deze rechtsfiguur onder het oude recht worden thans vragen opgeworpen, waarop door vooraanstaande (arbeids)rechtsgeleerden zoals Levenbach en Molenaar reeds in de jaren vijftig antwoord is gegeven. ${ }^{2}$ Wat dient te worden verstaan onder 'het treffen van een voorziening omtrent de rechtsgevolgen van de onderbreking van de arbeidsovereenkomst'? Heeft de werknemer recht op loon over de periode dat de arbeidsovereenkomst nog niet is hersteld? Herstelt de rechter de arbeidsovereenkomst of veroordeelt hij enkel de werkgever tot het herstellen van de overeenkomst? Wat als de werknemer na een veroordeling bij nader inzien toch niet wil meewerken aan de herstelveroordeling, pleegt hij dan wanprestatie? En behelst de herstelde arbeidsovereenkomst een nieuwe juridische overeenkomst?

Inmiddels heeft de Hoge Raad twee beschikkingen gewezen die op z'n zachtst gezegd niet bijdragen aan

* Ruben Houweling is hoogleraar Arbeidsrecht Erasmus School of Law Hij dankt S.R. Sripal voor zijn ondersteuning bij het empirisch onderzoek.

1. A.R. Houweling, 'Ken uw klassieken!', AR 2016-462.

2. Zie A.R. Houweling, 'Onbekend maakt onbemind: herstel van de arbeidsovereenkomst in het Nederlands ontslagrecht', in: A.R. Houweling (red.), De kennelijke onredelijkheid in beweging, Den Haag: Sdu Uitgevers 2013, p. 77-85 en E.F.V. Boot, 'Herstel van de arbeidsovereenkomst: onbekend, onbemind en ongebruikt?', TAP 2011-3, p. 93 e.v. duidelijkheid over deze rechtsfiguur. ${ }^{3}$ Zo lijkt de Hoge Raad in artikel 7:683 BW de bevoegdheid van de appelrechter te lezen om ook zelf de arbeidsovereenkomst te herstellen (in plaats van de werkgever daartoe te veroordelen). En of de Hoge Raad na herstel van een nieuwe juridische overeenkomst uitgaat, valt nog te bezien. Kortom, aanleiding voor een nadere analyse.

Dit artikel bestaat uit twee delen. In het eerste deel sta ik stil bij de theorie. De historische context van de rechtsfiguur van herstel wordt geschetst om vervolgens de verschillende opvattingen in de literatuur en de twee beschikkingen van de Hoge Raad (en de daarbij behorende conclusies) te analyseren in het licht van de 'herstelveroordeling' ( $(2)$. Daarna volgt in het tweede deel een analyse van de Wwz-rechtspraak (in totaal 90 beschikkingen) om daaruit conclusies te trekken hoe de rechtspraak omgaat met het verzoek tot veroordeling tot herstel van de arbeidsovereenkomst (\$3). Ik sluit af met een conclusie ( $(4)$.

\section{Herstelveroordeling: van dienstbetrekking naar arbeidsovereenkomst}

\subsection{Herstel der dienstbetrekking}

De rechtsfiguur van herstel van de arbeidsovereenkomst is een noviteit van de wetgever uit 1953/54 (wetsvoorstel 881). De herstelvordering (want destijds een dagvaardingsprocedure) werd toentertijd beschouwd als het resultaat van de 'moderne opvatting': de arbeidsovereenkomst droeg niet langer een dusdanig persoonlijk karakter dat toetsing van de ontslaggrond niet door derden kon geschieden en terugkeer zou zijn uitgesloten. Integendeel, bij onrechtmatig ontslag zou terugkeer naar het werk voortaan uitgangspunt zijn. ${ }^{4}$ Deze hoge verwachtingen zijn niet uitgekomen, getuige het handjevol

3. HR 23 december 2016, ECLI:NL:HR:2016:2998 (Mediant) en HR 31 maart 2017, ECLI:NL:HR:2017:571 (Vlisco).

4. Kamerstukken I/ 1947/48, 881, 3 en 37, p. 2. 
aan rechterlijke uitspraken omtrent de herstelveroordeling. ${ }^{5}$

De herstelvordering trof men oorspronkelijk aan in artikel 1639t BW onder de noemer 'herstel der dienstbetrekking'. De gekozen terminologie 'dienstbetrekking' is van betekenis. De wetgever ging namelijk uit van de gedachte dat de arbeidsovereenkomst door opzegging was geëindigd. Die opzegging - een eenzijdige rechtshandeling die het einde van de arbeidsovereenkomst met zich brengt - werd door de herstelveroordeling niet ongedaan gemaakt. De werkgever werd verplicht opnieum een arbeidsovereenkomst met de werknemer aan te gaan. Om de werkgever hiertoe nog meer te dwingen, werd expliciet gewezen op de mogelijkheid tot het opleggen van een dwangsom. ${ }^{6}$ Over het karakter van de herstelde overeenkomst lezen we bij Levenbach: 'Juist omdat herstel van de dienstbetrekking civielrechtelijk een nieuwe wilsovereenstemming van de beide partijen vergt, reikt de verplichting van de veroordeelde partij niet verder dan het opbrengen van de zijnerzijds daartoe vereiste wilsverklaring', en iets verderop: 'Aangezien echter het vonnis niet van rechtswege de oude dienstbetrekking doet herleven en juridisch een nieuwe overeenkomst wordt gesloten, zal voor het herstel van die bedingen uit de oude arbeidsovereenkomst, welke volgens de wet slechts schriftelijk mogen worden aangegaan, een nieuwe schriftelijke bevestiging nodig zijn.'7 Molenaar verwoordde het voorgaande als volgt: 'Indien herstel wordt bevolen, betekent dit niet dat de oude dienstbetrekking herleeft, noch dat zij geacht wordt nimmer te zijn beëindigd. De hoofdregel blijft ook hier van kracht: iedere verbreking van het contract, ook de meest onregelmatige of onredelijke, beëindigt de rechtsbetrekking tussen partijen. Er staat dan ook niet in de wet, dat de rechter herstelt, doch dat de rechter herstel beveelt', en iets verderop in zijn betoog: "De termen "herleven" en "herstellen" zijn in zoverre misleidend, dat zij het doen voorkomen alsof de onregelmatige of kennelijk onredelijke beëindiging eenvoudig weggedacht kan worden, zodat de dienstbetrekking doorloopt als ware er niets gebeurd. Niets echter is minder waar: de dienstbetrekking, welke er is na het herstel is een geheel nieuwe, op dezelfde, of op andere voorwaarden [als partijen daartoe zelf instemmen; toev. ARH] dan de oude aangegaan.' ${ }^{8}$ Ook Van den Heuvel spreekt van het 'weer tot stand brengen van de overeenkomst' in zijn dissertatie. ${ }^{9}$ Kortom, de herstelveroordeling leidt niet tot een automatisch herstel van de arbeidsovereenkomst, als ware het een soort tweederangs vernietiging van de opzegging. De herstelveroordeling leidt tot een verplichting van de werkgever zijn wil overeenkomstig de veroordeling te uiten, een rechterlijk gebod (vergelijkbaar met artikel 3:296 BW).

5. L.H. van den Heuvel, De redelijkheidstoetsing van ontslagen, Deventer: Kluwer 1983, p. 83 e.v.; Boot 2011, p. 93 e.v. en Houweling 2013, p. 77-85.

6. Kamerstukken I/ 1947/48, 881, 3, p. 10.

7. M.G. Levenbach, Het nieuwe burgerlijkrechtelijke ontslagrecht, Alphen aan den Rijn: Samsom 1954, p. 123-124.

8. A.N. Molenaar, Arbeidsrecht, Zwolle: Tjeenk Willink 1957, p. 212-213.

9. Van den Heuvel 1983, p. 82
Indien het gebod wordt opgevolgd, ontstaat een nieuwe juridische arbeidsovereenkomst, zodra en indien de werknemer daarmee instemt. Gezien het feit dat de werknemer zelf om herstel heeft verzocht, zal die instemming snel volgen.

\subsection{Van dienstbetrekking naar arbeids-}

verhouding naar arbeidsovereenkomst

$\mathrm{Nu}$ kan men tegenwerpen dat artikel 1639t BW uitging van herstel van de dienstbetrekking, terwijl de huidige wettelijke regeling spreekt van het veel engere begrip 'arbeidsovereenkomst'. Om verschillende redenen is deze tegenwerping zinledig.

Ten eerste bepaalt de huidige regeling, op gelijke wijze als de oude, dat de rechter de merkgever veroordeelt de arbeidsovereenkomst te herstellen. Kortom, de wettekst wijst duidelijk in de richting van geen automatisch herstel, enkel een veroordeling van de werkgever de arbeidsovereenkomst te herstellen. Kennelijk moet de werkgever in actie komen.

Ten tweede miskent men dan dat voor de Wwz herstel van de dienstbetrekking reeds was gewijzigd in herstel van de arbeidsovereenkomst. Daarvoor moeten we terug naar 1997; zoals bekend de niet inhoudelijke wijziging van het arbeidsrecht bij invoering van artikel 7.10 BW. De toenmalige regering heeft er in 1997 voor gekozen 'dienstbetrekking' te wijzigen in 'arbeidsverhouding': 'In plaats van de woorden "herstel van de dienstbetrekking" zijn de woorden "herstel van de arbeidsverhouding" gekomen. Doordat het woord dienstbetrekking in de huidige wet in meer dan één betekenis voorkomt - hier is het, anders dan op veel andere plaatsen, niet synoniem met arbeidsovereenkomst, maar duidt het een feitelijke situatie aan - is het onvoldoende eenduidig. Het is duidelijker een ander woord te gebruiken.' ${ }^{10}$

Bij de invoering van de Flexwet (1999) werd artikel 7:682 (oud) BW opnieuw aangepast. Aanvankelijk kon namelijk ook de werknemer worden veroordeeld de arbeidsovereenkomst met de werkgever te herstellen. Deze mogelijkheid werd geschrapt, omdat een dergelijke veroordeling de werknemersmobiliteit onnodig zou beperken. ${ }^{11}$ Bij deze wijziging werd opnieuw gesleuteld aan de terminologie van de herstelvordering: 'arbeidsverhouding' werd gewijzigd in 'arbeidsovereenkomst'. De uiterst summiere toelichting bij deze wijziging luidde als volgt: 'De wijziging van "arbeidsverhouding" in "arbeidsovereenkomst" in artikel 7:682 (oud) BW is bedoeld om een onbedoelde discrepantie in terminologie tussen deze bepaling en de overige bepalingen van titel $7.10 \mathrm{BW}$ op te heffen. ${ }^{12}$ De regering dacht er goed aan te doen in de hele titel 7.10 BW dezelfde terminologie te hanteren, maar realiseerde zich toen onvoldoende dat de wetgever in 1953 en 1997 welbewust had gekozen voor dienstbetrekking/arbeidsverhouding bij de herstelveroordeling, nu herstel van de reeds geëindigde arbeids-

10. Kamerstukken II 1993/94, 23438, 3, p. 52.

11. Zie Kamerstukken II 1996/97, 25263, 3.

12. Zie Kamerstukken I/ 1997/98, 25263, 14, p. 8. 
overeenkomst niet mogelijk is. Een inhoudelijke wijziging van artikel 7:682 (oud) BW was in ieder geval niet beoogd. Oftewel, de techniek bleef dezelfde.

Met de invoering van de Wwz is dit niet anders. De rechtsfiguur van herstel van de arbeidsovereenkomst wordt zowel naar oud recht als naar nieuw recht op eenzelfde wijze aangeduid, waaruit mag worden afgeleid dat men geen inhoudelijke wijziging heeft beoogd wat het rechtskarakter van de 'herstelde overeenkomst' betreft. Zo schrijft de regering in antwoord op het advies van de Raad van State: 'Ook in het huidige recht kennen we in deze situaties de figuur van herstel (mogelijkheid van herstel in kennelijk onredelijk ontslag procedure na oordeel UWV).' ${ }^{13}$ Kortom, aan de gewijzigde terminologie - van dienstbetrekking via arbeidsverhouding naar arbeidsovereenkomst - komt geen betekenis toe.

Ten derde, indien na een herstelveroordeling altijd sprake zou zijn van de oude arbeidsovereenkomst die gewoon doorloopt (al dan niet met een kleine onderbreking), dan zou de inhoud van artikel 7:672 lid 9 BW volstrekt overbodig zijn. In dit artikel is geregeld hoe de opzegtermijn van een herstelde arbeidsovereenkomst moet worden berekend. Het negende lid luidt als volgt: 'Voor toepassing van lid 2 worden arbeidsovereenkomsten [cursivering ARH] geacht eenzelfde, niet onderbroken arbeidsovereenkomst te vormen in geval van herstel van de arbeidsovereenkomst ingevolge artikel 682 of artikel 683.' De gehanteerde meervoudsvorm van arbeidsovereenkomst laat zien dat ook de wetgever uitgaat van een nieuwe (tweede) juridische overeenkomst. ${ }^{14}$ De kritische lezer zal hiertegen inbrengen dat iets verderop in de wet, te weten in artikel 7:682 lid 6 $\mathrm{BW}$, wordt gesproken van 'voorzieningen omtrent de gevolgen van de onderbreking van de arbeidsovereenkomst'. Oftewel, hier lijkt een duidelijk wettelijke contra-indicatie van de opvatting dat na herstel een nieuwe juridische verhouding ontstaat. Dé arbeidsovereenkomst wordt immers onderbroken, aldus het zesde lid. Leest men in plaats van 'arbeidsovereenkomst' 'arbeidsverhouding', zoals hierboven betoogd, dan is het een volstrekt begrijpelijke bepaling. De rechter treft voorzieningen voor de duur van de onderbreking van de arbeidsverhouding. Ik probeer mij ook een voorstelling te maken van een 'onderbroken arbeidsovereenkomst'. Een doorlopende overeenkomst met een tijdelijke onderbreking...? Hoe goed ik mijn best ook doe, het lukt niet hier een juridisch correcte voorstelling van te maken. Als twee mensen na een echtscheiding toch weer met elkaar in het huwelijksbootje stappen, dan is de relatie misschien weer hersteld, prachtig, maar het zijn toch echt twee huwelijken, met een onderbreking. Het eerste huwelijk loopt niet door, alsof er nooit een echtscheiding is geweest.

13. Zie onder meer Kamerstukken // 2013/14, 33818, 4, p. 57

14. Zie uitvoerig: A.R. Houweling (red.), Loonstra \& Zondag. Arbeidsrechtelijke themata, Den Haag: Boom Juridische uitgevers 2015, p. 761.
Ten slotte, mocht men nog twijfelen of de wetgever de herstelovereenkomst als een nieuwe overeenkomst heeft bedoeld, dan neemt de memorie van toelichting bij de Wwz die twijfel zonder meer weg: 'Het zesde lid [van artikel 7:682 BW; ARH] voorziet erin dat de rechter, als hij het verzoek van de werknemer inwilligt en de werkgever opdraagt de arbeidsovereenkomst te herstellen, bepaalt op welk tijdstip de overeenkomst wordt hersteld. Daarbij wordt in herinnering geroepen dat de arbeidsovereenkomst - anders dan bij een vernietiging van de opzegging - niet door de gerechtelijke beschikking zelf wordt hersteld. De rechter draagt de werkgever in de beschikking op om de werknemer een nieuwe arbeidsovereenkomst aan te bieden onder dezelfde voorwaarden als de vorige. Voor de bepaling van het aantal dienstjaren tellen de dienstjaren uit de vorige arbeidsovereenkomst mee; zie artikel 7:672, achtste lid (nieuw), BW. Ook bepaalt de rechter in zijn beschikking of een aan de werknemer toegekende transitievergoeding moet worden terugbetaald.' ${ }^{15}$

\subsection{Verval afkoopsom: toch een materiële wijziging?}

Er is wel een belangrijk verschil tussen de huidige en de oude regeling van herstel van de arbeidsovereenkomst. De oude regeling stond toe dat op verzoek van de werkgever de herstelveroordeling alsnog kon worden afgekocht (artikel 7:682 lid 3 (oud) BW). Die mogelijkheid is met de inwerkingtreding van de $\mathrm{Wwz}$ vervallen. Hoewel, vervallen...? Ja, als het gaat om een procedure bij de kantonrechter. Nee, als het gaat om een procedure bij het hof. Althans, betoogd kan worden dat de appelrechter ambtshalve mag overgaan tot het toekennen van een billijke vergoeding als alternatief voor de verzochte herstelveroordeling. ${ }^{16}$ De dan toe te kennen billijke vergoeding vertoont nauwe verwantschap met de oude afkoopsom. ${ }^{17}$ Voor de invulling van deze billijke vergoeding zou derhalve inspiratie kunnen worden ontleend aan deze afkoopsom. ${ }^{18}$ Met 'althans' trek ik niet in twijfel dat de appelrechter deze ambtshalve bevoegdheid toekomt, maar de mate waarin hij van deze bevoegdheid gebruik mag maken (zie hierna $\S 3$ ).

Het enkele feit dat het afkopen van de herstelveroordeling niet langer mogelijk is onder de $\mathrm{Wwz}_{\mathrm{w}}$, doet overigens niet af aan de opvatting dat door herstel een nieuwe juridische arbeidsovereenkomst ontstaat. De Wwz-wetgever heeft enkel de contractvrijheid nog verder ingeperkt: u zult herstellen en onder geen beding is die verplichting in eerste aanleg afkoopbaar! Overigens werd reeds bij de behandeling van artikel 1639t BW de vraag gesteld of de afkoopsom wel een plaats in het recht moest hebben. De toenmalige minister meende van wel, omdat denkbaar was dat herstel normaliter in de rede

15. Kamerstukken // 2013/14, 33818, 3, p. 119

16. Vgl. Hof Den Haag 29 november 2016, ECLI:NL:GHDHA:2016:3449, r.o. 2.29.

17. Zie Houweling c.s. 2015, p. 755

18. Zie over de afkoopsom naar oud recht O. van der Kind \& E.A. Jacz, 'De afkoopsom van art. 7:682 BW - een boete naar billijkheid volgens de kantonrechtersformule?', ArbeidsRecht 2013/60. 
lag, maar dat de verhouding tussen partijen inmiddels zodanig verstoord is geraakt dat de werkgever deze verplichting zou moeten afkopen (een soortgelijke redenering treffen we aan bij de ambtshalve toekenning van een billijke vergoeding in hoger beroep ex artikel 7:683 BW).

\subsection{Argumenten tegen een nieuwe juridische overeenkomst}

In de literatuur hebben vooral Chorus en Van Waegeningh ${ }^{19}$ stelling genomen tegen de opvatting dat na herstel sprake zou zijn van een nieuwe juridische overeenkomst. Daartoe voeren zij onder meer het volgende aan. Vanwege de rechterlijke dwang bij een veroordeling tot herstel kan moeilijk sprake meer zijn van 'wilsovereenstemming'. Ik ben het met de auteurs eens, dat van een zekere vrije wil geen sprake is. Maar die hoeft er ook niet te zijn, nu herstel door tussenkomst van een rechter wordt bevolen in een situatie waarin de arbeidsovereenkomst in retrospectief niet beëindigd had mogen worden. Van een zuiver 'willen' is dan geen sprake meer. Anderzijds kan de werkgever nog steeds weigeren uitvoering te geven aan de veroordeling (ook al komt hem dit mogelijk duur te staan door eventuele dwangsommen die aan het herstel gekoppeld kunnen zijn). Bovendien, is de fictie van Molenaar zo vreemd 'wilsoplegging' te aanvaarden? Waar de auteurs in ieder geval geen antwoord op hebben gegeven, is wat er met de initiële eenzijdige rechtshandeling, de opzegging, gebeurt. Er is een overeenkomst opgezegd. We kennen dan de rechts-

figuur van vernietiging van de rechtshandeling, waarmee de opzegging van tafel wordt geveegd (artikel 7:681 BW). En we kennen de situatie van herstel. Nu kunnen we materieel hetzelfde bereiken, namelijk dat de werknemer doorlopend op basis van dezelfde arbeidsvoorwaarden werk behoudt, maar hier is een juridisch andere constructie voor nodig.

Het tweede tegenargument dat door de auteurs wordt aangevoerd, is dat uit de wetsgeschiedenis zou blijken dat met herstel eigenlijk vernietiging wordt bedoeld, dan wel dat herstel materieel hetzelfde rechtsgevolg moet sorteren. Pas op, dit zijn twee verschillende en vergaande stellingen. De eerste stelling lijkt mij om de simpele reden dat is gekozen voor 'herstel' en niet 'vernietiging' al niet houdbaar. Maar er is meer. In de Wwz is juist gekozen voor een stelsel dat duidelijkheid geeft. Dus ontbinding in eerste aanleg leidt tot einde arbeidsovereenkomst. In hoger beroep kan er herstel plaatsvinden, maar geen vernietiging. Dat is een bewuste keuze geweest van de wetgever. Ook de Hoge Raad heeft in de Mediant-beschikking (maar die was tijdens het schrijven van de auteurs nog niet gewezen, dus dat valt hun niet aan te rekenen) duidelijk overwogen dat 'vernietiging' en 'herstel' twee van elkaar te onderscheiden rechtsfiguren zijn. Maar zelfs als we het citaat van de auteurs omarmen, dan brengt ons dat niet tot de door hen gewenste conclusie. 'Om echter het uitgangspunt recht

19. F.A. Chorus en S. van Waegeningh, 'In staat van ontbinding? De voorwaardelijke ontbinding onder de Wwz', ArbeidsRecht 2016/33. te doen en het rechtgevolg materieel gelijk te doen zijn met de voornoemde vernietiging, dient de rechter het herstel met terugwerkende kracht (...) op te dragen aan de werkgever.' Volgens mij zegt de regering hier heel duidelijk waar het op staat: de werkgever wordt opgedragen te herstellen. Hij (de werkgever) moet iets doen. Voor de echte techneuten onder ons zou het volgende nog denkbaar zijn. De werkgever ontslaat een werknemer op staande voet. De rechter wijst het vernietigingsverzoek af. In hoger beroep veroordeelt de appelrechter de werkgever de arbeidsovereenkomst te herstellen. Hoe zou de werkgever dat in plaats van een nieuwe arbeidsovereenkomst, wellicht ook nog kunnen doen? Betoogd zou kunnen worden dat de werkgever dan met terugwerkende kracht de eenzijdige rechtshandeling intrekt. Dat kan alleen met medewerking van de wederpartij, de werknemer, die vanwege zijn verzoek daartoe die medewerking zal verlenen. In die situatie loopt de oude arbeidsovereenkomst gewoon door, omdat de rechtshandeling is ingetrokken. Dat het een beetje vreemd voorkomt dat dit voor het eerst in hoger beroep na veroordeling plaatsvindt, is dan maar zo. Dus toch dezelfde overeenkomst? Maar wat nu als de appelrechter per heden of in de toekomst veroordeelt te herstellen, dan biedt intrekking geen soelaas meer, althans het is van tweeën een: of intrekking en doorlopende arbeidsovereenkomst of geen intrekking en nieuwe overeenkomst. Ik denk niet dat de wetgever dit scenario voor ogen had.

Als derde argument noemen zij het 'semantische argument': herstel betekent toch terugbrengen in de oude situatie? De lezer zal inmiddels mijn reactie vermoeden. Het gaat niet om het woordje 'herstel' het gaat om de verkeerde uitleg van 'arbeidsovereenkomst'. De arbeidsovereenkomst is door opzegging geëindigd. Die valt niet meer te herstellen. Vergelijk een huwelijk dat is ontbonden door echtscheiding. Een nieuw huwelijk sluiten staat iedereen vrij.

Ten slotte vatten de auteurs 'herstel' samen als een door de Wwz-wetgever beoogde 'praktische keuze' in plaats van vernietiging. Die praktische keuze zou voortvloeien uit het feit dat er ook een onderbreking kan plaatsvinden, wat bij vernietiging niet mogelijk is. Hiervoor heb ik al de vraag gesteld wat voor arbeidsovereenkomst dit is... een arbeidsovereenkomst met onderbrekingen. Volgens mij bestaat die niet.

\subsection{Conclusies van de advocaten-generaal en de parenthesen van de Hoge Raad}

Voornoemde auteurs vinden bijval van de advocatengeneraal bij de Mediant- en Vlisco-beschikking. Zo vindt A-G Keus (Mediant) dat ook een eventueel nog niet bestaande overeenkomst kan worden ontbonden en overigens leest hij de wettekst zo dat sprake is van eenzelfde overeenkomst. ${ }^{20}$ Volgens Quist en Doolaege kwam de Hoge Raad in de Mediant-beschikking niet toe aan een oordeel over het karakter van de 'herstelovereenkomst' en zij vonden de conclusie bij deze beschik-

20. Concl. A-G Keus 13 oktober 2016, ECLI:NL:PHR:2016:998, punt 5.19 
king vooral 'pragmatisch'. Hun voornaamste punt van kritiek is dat de A-G niet ingaat op de argumenten voor, maar enkel de argumenten tegen stipuleert. ${ }^{21}$ Drie maanden later vindt de herkansing plaats. A-G De Bock concludeert bij Vlisco: 'Naar mijn mening is dit [de herstelovereenkomst kan niet voorwaardelijk worden ontbonden omdat het een nieuwe juridische overeenkomst is; toev. ARH] argument niet erg overtuigend. Onder verwijzing naar de beschouwingen van A-G Keus in zijn conclusie voor de Mediant-uitspraak onder 5.19 (en 5.15) kan worden aangenomen dat in de ogen van de wetgever een herstelde overeenkomst in feite neerkomt op dezelfde overeenkomst. Niet is in te zien waarom geen ontbinding zou kunnen worden verzocht van een aldus herstelde arbeidsovereenkomst. Het komt mij voor dat een dergelijke, praktische benadering aansluit bij de oplossingsrichting die de Hoge Raad in de Mediant-uitspraak heeft gekozen. ${ }^{22}$ Begrijp ik de advocaat-generaal goed, dan vindt zij de herstelovereenkomst als nieuwe juridische overeenkomst wel heel vergezocht en is de gekozen oplossing wel zo praktisch.

En wat doet de Hoge Raad vervolgens? Bij eerste lezing van de beschikkingen kan het antwoord luiden: niets! Maar... bij nader inzien (b)lijkt de Hoge Raad zich wel degelijk in de discussie te mengen. In zowel de Mediant- als de Vlisco-beschikking gebruikt de Hoge Raad - kennelijk bewust want tot twee keer toe - parenthesen. Zo overweegt de Hoge Raad in r.o. 3.12.2 van de Mediant-beschikking: 'In een zodanig geval kan de appelrechter of de verwijzingsrechter (de werkgever veroordelen om) de arbeidsovereenkomst herstellen (...)' en op gelijke wijze in Vlisco: 'De Mediant-beschikking spreekt ten onrechte van "vernietiging". De desbetreffende passage moet aldus worden gelezen dat met de bevoegdheid van de appel- of verwijzingsrechter om op de voet van artikel 7:683 lid 3 BW (de werkgever te veroordelen) de arbeidsovereenkomst te herstellen of aan de werknemer een billijke vergoeding toe te kennen, welke bevoegdheid hij in volle omvang moet kunnen uitoefenen, onverenigbaar is dat de kantonrechter desverlangd de voorwaardelijk verzochte ontbinding van de arbeidsovereenkomst (ook) zou uitspreken voor het geval de appel- of verwijzingsrechter, anders dan de kantonrechter, zou oordelen dat het ontslag op staande voet ten onrechte is gegeven, en hij (de werkgever veroordeelt) de arbeidsovereenkomst herstelt (te herstellen).' [accenten ARH].

Waarom die haakjes? Waarom die parenthesen? Met zijn parenthesen 'de werkgever veroordelen om' wijkt de Hoge Raad uitdrukkelijk af van de wettekst. Dat is op zichzelf al interessant te concluderen: bij de eerste Wwz-uitspraak van de Hoge Raad wordt de wettekst gelijk losgelaten! Nu zou men kunnen verdedigen dat de parenthesen hier vooral als doel hebben iets te benadrukken, iets te verduidelijken, maar mij komt het toch eerder voor alsof de Hoge Raad de ruimte aan de rechter

21. J.P. Quist en D.N.C. Doolaege, 'Voorwaardelijke ontbinding na ontslag op staande voet: the story continues', TAP 2017-1, par. 4.1.

22. Concl. A-G De Bock 20 januari 2017, ECLI:NL:PHR:2017:21, punt 2.23. geeft hetzij de werkgever te veroordelen de arbeidsovereenkomst te herstellen, hetzij de arbeidsovereenkomst zelf te herstellen. In dat geval kan van een nieuwe juridische overeenkomst nauwelijks nog sprake zijn. Of moet het oordeel van de rechter als een soort 'indeplaatsstelling' worden opgevat? ${ }^{23}$ A-G De Bock is in ieder geval de mening toegedaan dat de rechter zelf kan herstellen. Een tweederangs vernietiging zullen we maar zeggen. Zij juicht dat om praktische redenen toe (want dan kan de appelrechter gelijk ontbinden!). Verhulp schrijft in zijn NJ-annotatie dat hij het met de A-G('s) eens is dat na herstel sprake is van dezelfde arbeidsovereenkomst. Een motivering waarom hij dat vindt ontbreekt. ${ }^{24} \mathrm{Ik}$ wijs een dergelijke benadering om juridisch-dogmatische redenen af. ${ }^{25}$ Zeker weten doen we het niet. En aangezien de Hoge Raad de Vlisco-beschikking nodig had om zijn Mediant-beschikking nader toe te lichten, zou het helemaal niet verkeerd zijn als er een derde beschikking van de Hoge Raad komt die ons duidelijkheid verschaft over de juridische status van de herstelovereenkomst.

\subsection{Tussenconclusie}

Wordt de discussie niet wat kinderachtig? Is het nu een nieuwe overeenkomst of niet? Wat makkt het uit? Als we gewoon allemaal doen alsof herstel een tweederangs vernietiging is, dan kunnen we verder. Ik kan mij voorstellen dat deze vragen inmiddels opdoemen bij de lezer.

Het maakt in juridische zin heel wat uit. Als herstel leidt tot een nieuwe juridische overeenkomst, dan kan voorwaardelijke ontbinding simpelweg niet. Op welke gronden van artikel 7:669 lid $3 \mathrm{BW}$ kan de rechter de arbeidsovereenkomst ontbinden, als die nog moet worden aangegaan? Dat is simpelweg niet mogelijk. Dat kan alleen als je als rechter de arbeidsovereenkomst zelf herstelt, om daarna weer te ontbinden. Wellicht dat dit de reden is dat de Hoge Raad in Vlisco de parenthesen heeft gehandhaafd. Immers, in zijn Vlisco-beschikking overweegt de Hoge Raad dat de appelrechter voorwaardelijk kan ontbinden. Dekker signaleert in zijn noot bij Vlisco eveneens deze complicatie. Hij is van mening dat ook een nieuwe juridische overeenkomst ontbonden moet kunnen worden, omdat het verschil met de situatie van vernietiging in materieel opzicht niet zo groot is en het dus moet kunnen. ${ }^{26}$

Als sprake is van een nieuwe juridische arbeidsovereenkomst onder dezelfde voorwaarden, hoe zit het dan met zogenoemde bezwarende bedingen als die overeenkomst niet schriftelijk is aangegaan? Zijn die dan niet rechtsgeldig overeengekomen? Of passen we hier de leer toe dat een beding eenmaal rechtsgeldig aangegaan, alleen opnieuw schriftelijk overeengekomen hoeft te worden in

23. Zie voor een fraaie analyse van de parenthesen van de Hoge Raad de noot van D.A.D. Mees in JIN 2017/90, bij HR 31 maart 2017, ECLI:NL:HR:2017:571 (Vlisco).

24. NJ 2017/204 m.nt. E. Verhulp onder 9

25. Met mij ook F.M. Dekker, 'Voorwaardelijke ontbinding in hoger beroep', AR 2017-0392.

26. F.M. Dekker, 'Voorwaardelijke ontbinding in hoger beroep', $A R$ 2017-0392. 
geval van 'zwaarder drukken', bijvoorbeeld? Dit biedt wellicht uitkomst voor het concurrentiebeding, maar geeft op veel andere bedingen geen antwoord. Verdedigbaar is dan dat bij 'behoud van identiteit van de overeenkomst' (hetgeen bij herstel het uitgangspunt is) initieel schriftelijk overeengekomen bedingen hun geldigheid behouden. Worden evenwel bij het aangaan van een nieuwe overeenkomst aanvullende afspraken gemaakt waarmee de identiteit wijzigt, dan is hernieuwde vastlegging van de bezwarende bedingen op zijn plaats. Een andere consequentie zou zijn dat de werkgever - ook bij herstel met terugwerkende kracht - de transitievergoeding voor het beëindigen van voorgaande arbeidsovereenkomst verschuldigd is en blijft. In de parlementaire geschiedenis is opgemerkt dat bij herstel met terugwerkende kracht tot datum einde dienstverband, de werknemer de transitievergoeding moet terugbetalen, maar daarvoor is geen wettelijke grondslag.

Maar betekent dit ook dat een werknemer zijn anciënniteit verliest en dus bij een tweede bedrijfseconomisch ontslag opeens onderaan de afspiegelingsladder staat? Het antwoord op deze vraag moet worden gezocht in de regeling omtrent afspiegeling. In artikel 15 Ontslagregeling treffen we aan dat indien sprake is van opeenvolgende arbeidsovereenkomsten tussen dezelfde partijen binnen zes maanden, de arbeidsovereenkomsten bij elkaar worden opgeteld. Ook in andere gevallen regelt de wet de rechtsgevolgen in specifieke situaties. Ik noemde reeds de samentelling bij de berekening van de opzegtermijn (artikel 7:672 lid 9 BW). Maar ook de transitievergoeding voorziet in een samentelregeling (artikel 7:673 lid 4 en 5 BW). Het aanvaarden van een nieuwe juridische overeenkomst kan soms vergaande gevolgen hebben, als bijvoorbeeld de pensioenuitvoerder niet meer bereid is tegen de oude voorwaarden de werknemer opnieuw aan te melden. Of dat werknemer hierdoor een bepaalde cao-aanspraak misloopt. Indien zich dit voordoet, dan zou de werknemer aan de rechter moeten vragen hiervoor voorzieningen te treffen (artikel 7:682 lid 6 jo. artikel 7:683 lid 4 BW).

Natuurlijk zijn al deze ingewikkelde vragen gemakkelijk op te lossen als we aanvaarden dat herstel gewoon 'een soort' vernietiging is. So what's the point? My point is, dat juist de rechtswetenschap als taak heeft te waken voor systematisch en juridisch redeneren. Als vernietiging en herstelveroordeling hetzelfde is, dan is vernietiging en ontbinding dat straks ook en is er eigenlijk ook geen verschil meer tussen een wanprestatie en onrechtmatige daad. Laten wij alsjeblieft de wetgever scherp houden en confronteren met de juridische werkelijkheid die hij creëert. Dat de wetgever dan mogelijk overgaat tot aanpassing van de wet, in bijvoorbeeld een stelsel waarin de kantonrechter een opzegging met toestemming van het UWV gewoon kan vernietigen omdat achteraf toch blijkt dat sprake is van een onrechtmatigheid, dan wel dat het hof de ontbindingsbeschikking van de kantonrechter kan vernietigen omdat er fouten zijn gemaakt, waarbij eventueel de automatisch terugwer- kende kracht van de vernietiging kan worden ontnomen (artikel. 3:53 lid 2 BW biedt daarvoor ook mogelijkheden waar het de rechtshandeling betreft; bij vernietiging van een beschikking zou dit in een wettelijke regeling tot uitdrukking moeten komen), is alleen maar te billijken.

\section{Rechtspraak}

Tot zover de theorie. Hoe wordt in de rechtspraak met de rechtsfiguur van herstel omgegaan? Sinds de invoering van de Wwz tot en met 30 april 2017 zijn er inmiddels 25 '682-beschikkingen' gewezen waarin een herstelverzoek aan de orde was en 65 ' 683 -beschikkingen'. ${ }^{27}$ Deze rechtspraak geeft het volgende beeld weer.

\subsection{Herstel ex artikel 7:682 BW: niet vaak gehonoreerd}

In de periode van 1 juli 2015 tot 30 april 2017 zijn in totaal vijfentwintig beschikkingen onderzocht en geanalyseerd, waarin de kantonrechter in negentien gevallen (76\%) overgaat tot afwijzing van het verzoek van de werknemer, strekkende tot herstel van de arbeidsovereenkomst dan wel tot toekenning van een billijke vergoeding. In de overige zes gevallen (24\%) gaat de kantonrechter over tot toewijzing van het verzoek van de werknemer, strekkende tot herstel van de arbeidsovereenkomst dan wel tot toekenning van een billijke vergoeding.

In drie van die zes gevallen (12\% van het totaal) heeft de kantonrechter de werkgever ertoe verplicht de arbeidsovereenkomst te doen herstellen. In deze gevallen heeft de kantonrechter vastgesteld dat het UWV de werkgever ten onrechte toestemming heeft verleend om de arbeidsovereenkomst op te zeggen. De omstandigheden waaronder de kantonrechter dit oordeel heeft bekomen, lopen echter uiteen. In het eerste geval had de werkgeefster onvoldoende duidelijk gemaakt dat de werkzaamheden van de werknemer niet langer in lijn waren met de doelstellingen van de werkgeefster en dat er in deze functie derhalve geen werk meer was. Naar het oordeel van de kantonrechter kon hieruit geen redelijke grond voor opzegging gedestilleerd worden. ${ }^{28}$ In het tweede geval was de opzegging in strijd met de a-grond, omdat onvoldoende acht was geslagen op de herplaatsingsmogelijkheden. ${ }^{29}$ In het derde en laatste geval was de opzegging in strijd met de a-grond, omdat de werkgever onvoldoende aannemelijk had gemaakt dat de arbeidsplaats van de werknemer was komen te vervallen ten gevolge van bedrijfseconomische redenen. ${ }^{30}$

In de resterende drie gevallen (12\% van het totaal) heeft de kantonrechter een billijke vergoeding aan de werknemer toegekend. ${ }^{31}$ In het eerste geval kon het ernstig ver-

27. In het onderzoek zijn alleen werknemersverzoeken betrokken. Het aantal van 58 beschikkingen is derhalve maar een deel van het totaal aantal hogerberoepszaken ex artikel 7:683 BW.

28. Rb. Amsterdam 22 april 2016, ECLI:NL:RBAMS:2016:2601

29. Rb. Noord-Holland 9 juni 2016, ECLI:NL:RBNHO:2016:4789.

30. Rb. Noord-Holland 14 juni 2016, ECLI:NL:RBNHO:2016:8196.

31. Kamerstukken / 2013/14, 33818, C, p. 115. 
wijtbaar handelen of nalaten aan de zijde van de werkgever worden afgeleid uit een 'uit de hand gelopen teamoverleg waarin de werknemer zwart werd gemaakt' ${ }^{32}$ In het tweede geval kende de kantonrechter aan de werknemer een billijke vergoeding toe op de grond dat de werknemer op de zitting geen herstel van de dienstbetrekking vorderde. Het ernstig verwijtbaar handelen van de werkgever was gelegen in het feit dat hij de arbeidsovereenkomst in strijd met het bepaalde in artikel 7:671 BW zou hebben opgezegd. ${ }^{33}$ In het derde geval was de werkneemster door haar werkgever op zodanige wijze onbehoorlijk behandeld, dat van ernstig verwijtbaar handelen sprake was. In dit kader kwam met name betekenis toe aan de omstandigheid dat de werkneemster zonder 'behoorlijke inlichting' op non-actief was gesteld en dat haar de toegang tot de werkplaats was ontzegd door de sloten van de deuren te veranderen. ${ }^{34}$

\subsection{Herstel ex artikel 7:683 BW: een op vier verzoeken leidt tot herstel}

In dezelfde onderzoeksperiode zijn in totaal vijfenzestig 7:683 lid 3-beschikkingen onderzocht en geanalyseerd. In dit verband vormden twee gevallen, die zich in het kader van het derde lid van artikel 7:683 BW kunnen voordoen, het uitgangspunt. In de eerste plaats gaat het om de gevallen waarin de rechter oordeelt dat het werkgeversverzoek tot ontbinding van de arbeidsovereenkomst ten onrechte is toegemezen. In de tweede plaats gaat het om de gevallen waarin de rechter oordeelt dat het werknemersverzoek tot hetzij vernietiging van de opzegging van het ontslag op staande voet, hetzij herstel van de (ontbonden) arbeidsovereenkomst ten onrechte is afgemezen. Ten aanzien van de voornoemde gevallen is onderzocht op welke wijze de rechter zijn bevoegdheid ex artikel 7:683 lid 3 BW uitoefent. Deze bevoegdheid bestaat uit twee elkaar uitsluitende mogelijkheden, te weten: de veroordeling van de werkgever tot herstel van de arbeidsovereenkomst (enerzijds) en, indien en voor zover herstel niet langer in de rede ligt, de toekenning van een billijke vergoeding aan de werknemer (anderzijds). In dit onderzoek is niet betrokken de omstandigheid waarin de werknemer een billijke vergoeding op de voet van artikel 7:681 BW verzoekt.

In negenendertig gevallen $(60 \%)$ liet de appelrechter het oordeel van de kantonrechter in stand en ging hij over tot afwijzing van het verzoek van de werknemer, strekkende tot herstel van de arbeidsovereenkomst dan wel tot toekenning van een billijke vergoeding. In de overige zesentwintig gevallen $(40 \%)$ heeft de appelrechter het werknemersverzoek toegewezen, en in het verlengde daarvan zijn bevoegdheid, zoals neergelegd in het derde lid van artikel 7:683 BW, uitgeoefend.

In veertien van de zesentwintig gevallen $(22 \%$ van het totaal) heeft de appelrechter de werkgever veroordeeld

32. Rb. Midden-Nederland 22 februari 2017, ECLI:NL:RBMNE:2017:543.

33. Rb. Limburg 20 maart 2017, ECLI:NL:RBLIM:2017:2517.

34. Rb. Rotterdam 11 mei 2016, ECLI:NL:RBROT:2016:3578. de arbeidsovereenkomst te doen herstellen. ${ }^{35}$ In twaalf van de zesentwintig gevallen (18\% van het totaal) heeft hij, in plaats van een herstelveroordeling, een billijke vergoeding aan de werknemer toegekend. ${ }^{36}$ In zes van de twaalf gevallen $(50 \%)$ heeft hij daartoe ambtshalve beslist. De redenen voor de toepassing van de ambtshalve bevoegdheid tot toekenning van een billijke vergoeding zijn verschillend.

\subsection{Herstel vrijwel altijd met terugwerkende kracht; een kwart van de herstelverzoeken ambtshalve omgezet in billijke vergoeding} Analyseren we de uitspraken nader, dan valt op dat in maar drie gevallen de rechter 'per heden' tot herstel veroordeelde. ${ }^{37}$ In alle andere gevallen werd herstel met terugwerkende kracht bevolen. Steeds veroordeelt de rechter de werkgever de arbeidsovereenkomst te herstellen. Er vindt dus een opdracht aan de werkgever plaats en geen herstel door de rechter zelf.

In gelijke zin valt op dat in appel veel terughoudender wordt omgegaan met het ambtshalve toekennen van een billijke vergoeding als alternatief voor herstel, dan de wetgever voorspelde. ${ }^{38}$ De wetgever heeft in de parlementaire geschiedenis benadrukt dat de appelrechter 'gezien het tijdsverloop' vermoedelijk vaak zal overgaan tot het toekennen van een billijke vergoeding. ${ }^{39}$ In minder dan een kwart van de herstelverzoeken blijkt hij

35. Hof Arnhem-Leeuwarden 15 februari 2016, ECLI:NL:GHARL: 2016:1116; Hof Den Bosch 28 april 2016, ECLI:NL:GHSHE:2016:1717 Hof Den Bosch 30 juni 2016, ECLI:NL:GHSHE:2016:2643; Hof Den Bosch 30 juni 2016, ECLI:NL:GHSHE:2016:2642; Hof Den Haag 23 augustus 2016, ECLI:NL:GHDHA:2016:2422; Hof Den Bosch 1 september 2016, ECLI:NL:GHSHE:2016:3994; Hof Arnhem-Leeuwarden 2 september 2016, ECLI:NL:GHARL:2016:7100; Hof Arnhem-Leeuwarden 5 oktober 2016, ECLI:NL:GHARL:2016:7962; Hof Arnhem-Leeuwarden 23 november 2016, ECLI:NL:GHARL:2016:9402; Hof Den Bosch 1 december 2016, ECLI:NL:GHSHE:2016:5341; Hof ArnhemLeeuwarden 2 december 2016, ECLI:NL:GHARL:2016:9733; Hof Den Bosch 8 december 2016, ECLI:NL:GHSHE:2016:5467; Hof ArnhemLeeuwarden 14 december 2016, ECLI:NL:GHARL:2016:10148; Hof Arnhem-Leeuwarden 19 april 2017, ECLI:NL:GHARL:2017:3495.

36. Hof Arnhem-Leeuwarden 22 april 2016, ECLI:NL:GHARL:2016:3215; Hof Den Haag 21 juni 2016, ECLI:NL:GHDHA:2016:1750; Hof Den Bosch 23 juni 2016, ECLI:NL:GHSHE:2016:2512; Hof Den Haag 27 september 2016, ECLI:NL:GHDHA:2016:2754; Hof Amsterdam 11 oktober 2016, ECLI:NL:GHAMS:2016:4118; Hof Den Bosch 10 november 2016, ECLI:NL:GHSHE:2016:5001; Hof Arnhem-Leeuwarden 22 december 2016, ECLI:NL:GHARL:2016:10426; Hof Arnhem-Leeuwarden 13 januari 2017, ECLI:NL:GHARL:2017:253; Hof Arnhem-Leeuwarden 19 april 2017, ECLI:NL:GHARL:2017:3494; Hof Den Haag 13 december 2016, ECLI:NL:GHDHA:2016:3611; Hof Den Haag 29 november 2016, ECLI:NL:GHDHA:2016:3449; Hof Den Bosch 24 maart 2016, ECLI:NL:GHSHE:2016:1093.

37. Hof Arnhem-Leeuwarden 2 september 2016, ECLI:NL:GHARL: 2016:7100; Hof Arnhem-Leeuwarden 2 december 2016, ECLI:NL:GHARL:2016:9733; Rb. Amsterdam 22 april 2016, ECLI:NL:RBAMS:2016:2601.

38. Zie in gelijke zin D.M.A. Bij de Vaate, 'Ontslagprocesrecht: perikelen in hoger beroep sinds 1 juli 2015', ArbeidsRecht 2017/1, par. 2.2.

39. Kamerstukken // 2013/14, 33818, 4, p. 58. 
gebruik te maken van zijn bevoegdheid aan de werknemer een billijke vergoeding toe te kennen. ${ }^{40}$

Het enkele tijdsverloop lijkt onvoldoende om ambtshalve toekenning van een billijke vergoeding te rechtvaardigen. ${ }^{41}$ Er zullen bijkomende omstandigheden moeten zijn; bijvoorbeeld dat herstel een onevenredig zware belasting zou zijn voor de werkgever, omdat deze laatste bijvoorbeeld een nieuwe kracht heeft aangenomen. ${ }^{42}$

\subsection{Verschuldigdheid van de transitievergoeding ná een herstelveroordeling}

In de parlementaire geschiedenis heeft de wetgever ten aanzien van de transitievergoeding het volgende opgemerkt: 'Benadrukt wordt dat wanneer de werknemer reeds een transitievergoeding heeft ontvangen maar vervolgens zijn verzoek om vernietiging van de opzegging wordt toegewezen hij de transitievergoeding zal moeten terugbetalen, aangezien de opzegging dan met terugwerkende kracht geacht wordt nooit te hebben bestaan. Bij herstel van de arbeidsovereenkomst zal dat ook het geval zijn bij een herstel met ingang van de ontbindingsdatum, en in overige situaties afhangen van de omstandigheden van het geval. ${ }^{43}$

Opvallend is dat de wetgever ervan uitgaat dat de transitievergoeding terugbetaald zal moeten worden vanwege het feit dat vernietiging van de opzegging bewerkstelligt dat dit laatste geacht wordt nimmer te hebben plaatsgevonden. Anders gezegd: de transitievergoeding moet worden terugbetaald, omdat de rechtsgrond waarop de verschuldigdheid ervan steunt niet langer aanwezig is, althans ontbreekt. De vraag rijst echter in hoeverre diezelfde redenering naar analogie kan worden toegepast op ontbinding van de arbeidsovereenkomst. Indien de rechter overgaat tot een herstelveroordeling moet worden aangenomen dat de arbeidsovereenkomst reeds in eerder stadium is geëindigd en dat de werkgever derhalve verplicht is aan de werknemer onder dezelfde voorwaarden een nieuwe arbeidsovereenkomst aan te bieden. Anders dan bij vernietiging van de opzegging, blijft in geval van herstel van de arbeidsovereenkomst dus wél een rechtsgrond bestaan op grond waarvan de transitievergoeding verschuldigd is.

Toch zien we in de rechtspraak de opvatting van de wetgever terugkeren. Zo oordeelde 'Hof Den Bosch in zijn beschikking van 8 december 2016 het volgende:

'Het hof is dus van oordeel dat de arbeidsovereenkomst ten onrechte is ontbonden, zodat het hof

40. Hof Den Haag 21 juni 2016, ECLI:NL:GHDHA:2016:1750; Hof Den Haag 27 september 2016, ECLI:NL:GHDHA:2016:2754; Hof ArnhemLeeuwarden 22 april 2016, ECLI:NL:GHARL:2016:3215; Hof Amsterdam 11 oktober 2016, ECLI:NL:GHAMS:2016:4118; Hof Den Bosch 23 juni 2016, ECLI:NL:GHSHE:2016:2512; Hof Den Bosch 10 november 2016, ECLI:NL:GHSHE:2016:5001.

41. Uit het onderzoek vloeit voort dat de looptijd tussen de uitspraak in eerste aanleg en de uitspraak in hoger beroep gemiddeld zeven tot acht maanden bedraagt en in het uiterste geval kan oplopen tot tien maanden.

42. Kamerstukken / 2013/14, 33818, C, p. 115. Zie ook Hof Arnhem-Leeuwarden 22 april 2016, ECLI:NL:GHARL:2016:3215.

43. Kamerstukken // 2013/14, 33818, 3, p. 39. [werkgever] zal veroordelen de arbeidsovereenkomst te herstellen. [appellant] heeft verzocht de beschikking waarvan beroep te vernietigen. Wel zal het hof de veroordeling van [werkgever] tot betaling van de transitievergoeding vernietigen, omdat een redelijke uitleg van de bepalingen van de Wwz ertoe leidt dat [appellant] als gevolg van de veroordeling tot herstel van de arbeidsovereenkomst geen recht meer behoudt op de transitievergoeding. Het hof zal het verzoek van [appellant] om [werkgever] te veroordelen tot herstel van de arbeidsovereenkomst, toewijzen. ${ }^{24}$

Maar ook de tegenovergestelde opvatting keert in de rechtspraak terug: 'Bovendien heeft [verzoeker] een transitievergoeding ontvangen, die blijkens de parlementaire geschiedenis van artikel 7:673 BW deels ziet op de gevolgen van een beëindiging van het dienstverband, waaronder ook begrepen gemist pensioen. Bij herstel van de arbeidsovereenkomst blijft de stichting deze verschuldigd en [verzoeker] hoeft die dan ook niet terug te betalen. Weliswaar kan dit bedrag verrekend worden in de situatie als bedoeld in artikel 7:673 lid 4 onder $b$ in combinatie met lid $5 \mathrm{BW}$, maar dat staat er niet aan in de weg dat [verzoeker] thans een deel kan aanwenden om gemist pensioen te compenseren. ${ }^{45}$

\section{Conclusie}

Er zijn onder de Wwz meer herstelveroordelingen gewezen dan in de 60 jaar dat de rechtsfiguur daarvoor al in ons wetboek bestond. Het is dan ook niet zo gek dat veel 'oude vragen' in rechtspraak en literatuur hernieuwde aandacht krijgen. Is de herstelde arbeidsovereenkomst een nieuwe juridische overeenkomst of niet? Moet de transitievergoeding worden terugbetaald bij herstel? Et cetera. De Wwz-rechtspraak laat zien dat de feitenrechters inmiddels ervaring opdoen met de herstelovereenkomst. Anders dan werd verwacht door de wetgever, is herstel een serieuze rechtsfiguur die regelmatig wordt toegepast. Naar mijn stellige overtuiging is een herstelde overeenkomst niets anders dan een nieuwe arbeidsovereenkomst onder dezelfde voorwaarden. Dat heeft tal van implicaties voor bijvoorbeeld het vraagstuk van voorwaardelijke ontbinding, verschuldigdheid van de transitievergoeding, geldigheid van bezwarende bedingen, enzovoort. Elke andere opvatting is er een gedreven op pragmatisme en juridisch-dogmatisch niet houdbaar. Uit het rechtspraakonderzoek leid ik af dat veel rechters de herstelveroordeling ook opvatten als een nieuwe juridische overeenkomst. Daarbij moet wel de kanttekening worden geplaatst dat het merendeel van de uitspraken is gewezen voor de beschikkingen van de Hoge Raad. Enige twijfel bestaat er bij rechters over de verschuldigdheid van de transitievergoeding na herstel, omdat het vaak niet 'goed voelt' dat iemand de transitievergoeding

44. Hof Den Bosch 8 december 2016, ECLI:NL:GHSHE:2016:5467, r.o. 3.17.

45. Rb. Amsterdam 22 april 2016, ECLI:NL:RBAMS:2016:2601, r.o. 15. 
opstrijkt terwijl zijn arbeidsverhouding hersteld is. Doorgaans wordt de werkgever veroordeeld de arbeidsovereenkomst met terugwerkende kracht te herstellen. Of de Hoge Raad de herstelde arbeidsovereenkomst ook als een nieuwe juridische overeenkomst beschouwt met alle gevolgen van dien, horen we hopelijk snel genoeg (met of zonder parenthesen). 